\title{
Physiological mechanism for the reduction in soil water in poplar (Populus deltoides) plantations in Dongting Lake wetlands
}

\author{
Youzhi Li • Hongyan Qin • Yonghong Xie • \\ Wei Wang $\cdot$ Xinsheng Chen $\cdot$ Canming Zhang
}

Received: 3 March 2013 / Accepted: 19 August 2013/Published online: 25 August 2013

(C) The Author(s) 2013. This article is published with open access at Springerlink.com

\begin{abstract}
The use of large-scale tree plantations has provoked increasing concern regarding the negative effects on local environments in different ecosystems. However, the physiological mechanism underlying the reduction in soil water by tree plantations in wetlands is not clear. The aims of this study were to investigate the effects of poplar (Populus deltoides) plantations on soil water content and to elucidate the underlying physiological mechanisms. To this end, we conducted a 1-year fixed-plot investigation of soil water content (SWC), plant photosynthetic rate (Pn), stomatal conductance (Gs), transpiration rate ( $\mathrm{Tr}$ ), and water-use efficiency (WUE) of individual leaves of 11- and 5-year-old poplars and of reed (Triarrherca sacchariflora, a native herbaceous plant) in the Dongting Lake wetlands, China. SWC was highest
\end{abstract}

Y. Li · H. Qin

College of Bioscience and Technology, Hunan

Agricultural University, Changsha 410128, China

Y. Li · Y. Xie $(\bowtie) \cdot$ W. Wang $\cdot$ X. Chen

Key Laboratory of Agro-ecological Processes in

Subtropical Region, The Chinese Academy of Sciences,

Changsha 410125, China

e-mail: yonghongxie@163.com

\section{Y. Li - C. Zhang}

Hunan Academy of Forestry, Changsha 410004, China

\section{Y. Xie $\cdot$ X. Chen}

Dongting Lake Station for Wetland Ecosystem Research, Institute of Subtropical Agriculture, The Chinese

Academy of Sciences, Changsha 410125, China in reed, intermediate in 11-year-old poplar, and lowest in 5-year-old poplar, suggesting that poplar plantations produce a lower soil water content in wetlands. From May to July, Pn was significantly higher in reed than in the two poplar stands, but did not differ between the different-aged poplars. As a whole, Gs and $\operatorname{Tr}$ were higher, but WUE was lower, in the poplar stands than in reed during the growing season, indicating that Gs and $\mathrm{Tr}$ are the key physiological mechanisms associated with the lower soil water in poplar stands. Relationships among Pn, Gs, and Tr showed positive correlations $(P<0.01)$ for each type of vegetation. These data suggest that poplar plantations may cause the transformation of wetlands into dry land due to a lower WUE leading to a massive water loss from soil. This, in turn, would have an influence on community composition and ecosystem function after establishment of the plantations.

Keywords Soil water content · Photosynthetic rate - Stomatal conductance - Transpiration rate . Water-use efficiency

\section{Introduction}

The use of fast-growing tree plantations has been increasing throughout the world to satisfy demands for industrial timber and pulp, to mitigate climatic changes (Richards et al. 2007), and to produce biofuels 
(IEA 2004). Tree species used in plantations include eucalyptus (Gerber 2011), rubber (Tan et al. 2011), pines (Licata et al. 2008), and poplars (Perry et al. 2001). Fast-growing trees are generally planted in monocultures, and these species have obvious advantages over native plants in competing for light, nutrients, and water resources. These factors have led to increasing concerns regarding the negative effects of large-scale tree plantations on local environments, including nutrition depletion (Onyekwelu et al. 2006), reduced biodiversity (Morris et al. 2008), water-table decline (Almeida et al. 2007), and outbreaks of pests and diseases (Kelty 2006).

The water-pumping effects of fast-growing tree plantations have been clarified in different ecosystems, such as in semiarid areas (Wilske et al. 2009; Tan et al. 2011) and wetlands (Le Maitre et al. 2002; Hernández-Santana et al. 2008; Migliavacca et al. 2009). For example, poplar plantations have the potential to extract groundwater and to reduce the water table in wetland ecosystems (Migliavacca et al. 2009). Excessive loss of soil water caused by tree plantations would influence community structure and ecosystem function (Gaitán et al. 2011). However, compared to groundwater, soil moisture content can more closely reflect the water status of the rhizosphere of tree plantations, which is more important in terms of regulating species distribution, community composition, and biodiversity (Engelbrecht et al. 2007; Gaitán et al. 2011). To date, the effects of tree plantations on soil water status have remained far from clear.

The mechanisms underlying the effects of tree plantations on soil water status are complex. Studies have shown that plant transpiration accounts for over $60 \%$ of evapotranspiration (Almeida et al. 2007) and for approximately $50 \%$ of total rainfall (Huang et al. 2011). Tree plantations usually have higher rates of transpiration than native vegetation (Granier et al. 2000; Schiller et al. 2007; Licata et al. 2008), due to higher stomatal conductance, which leads to greater water loss (Wallace and McJannet 2010; Chen et al. 2011). In addition, photosynthetic rate is closely linked to transpiration rate and has been suggested to provide a direct indication of water consumption because higher photosynthesis is usually associated with higher utilization efficiency of water resources (Licata et al. 2008; Wallace and McJannet 2010). It therefore appears that the physiological mechanism for high water loss in fast-growing tree plantations is closely related to the high rates of photosynthesis, transpiration, and stomatal activity in these systems.

Poplar (Populus deltoides), a fast-growing tree, is the dominant species in broadleaf forests in China (Fang et al. 2005). In 2003, poplar accounted for $13.5 \%$ of total forest plantation area in China (CFS 2003). In 1970, the alien $P$. deltoides was introduced into the Yangtze River basin for schistosome control. For example, the area in the Dongting Lake wetlands covered by tree plantations increased from $87 \mathrm{~km}^{2}$ in 1983 to $640 \mathrm{~km}^{2}$ in 2007 (approximately $26 \%$ of the wetland area), replacing the habitat of native herbaceous species, which were the dominant vegetation in the Dongting Lake wetlands (Xie and Chen 2008). These poplar plantations have provoked serious concern regarding increases in soil desiccation and a reduction in biodiversity (Chang et al. 2006; Liang et al. 2006; Migliavacca et al. 2009; Wilske et al. 2009; Yang et al. 2009). In the semiarid Loess Plateau, water consumption of poplar decreases with reductions in soil water content (Liang et al. 2006), suggesting that soil water loss may also be higher in wetlands due to the saturated conditions in these areas. In the research presented here, we conducted a 1-year fixed-plot study of 11- and 5-year-old poplar plantations, and of reed (Triarrherca sacchariflora, a native herbaceous perennial), to test the following hypotheses: first, the soil water content will be lower in poplar than in reed areas; second, photosynthetic rate, transpiration rate, and stomatal conductance will be higher in poplars than in reeds.

\section{Materials and methods}

\section{Study sites}

The Yangtze River is connected to Dongting Lake through 3 inlets (Songzikou, Taipingkou, Ouchikou) and 1 outlet (Chenglingji). Dongting Lake is the second largest freshwater lake in China and covers an area of $2,625 \mathrm{~km}^{2}\left(28^{\circ} 38^{\prime}-29^{\circ} 45^{\prime} \mathrm{N}, 111^{\circ} 40^{\prime}-113^{\circ} 10^{\prime} \mathrm{E}\right)$. The lake is characterized by a subtropical monsoon climate, with an average annual temperature of 16.2$17.8{ }^{\circ} \mathrm{C}$ and $259-277$ frost-free days per year. Mean annual precipitation ranges from 1,200 to $1,415 \mathrm{~mm}$, with the rainy season from April to August; average humidity is $80 \%$, and average evaporation is $1,270 \mathrm{~mm}$ (Cui et al. 2012). The annual mean wind 
speed is $2.0-3.0 \mathrm{~m} \mathrm{~s}^{-1}$ and the elevation is $28-35 \mathrm{~m}$ above sea level (a.s.l). Poplars have been planted extensively for industrial pulp since 1970, and have become the dominant vegetation in the Dongting Lake area.

Our study site was located on the beach of the Yangtze River, Guangxingzhou Town $\left(29^{\circ} 32^{\prime} \mathrm{N}\right.$, $112^{\circ} 55^{\prime} \mathrm{E}$ ), Yueyang City, Hunan Province, China. The site is approximately $15 \mathrm{~km}$ from the Chenglingji outlet and belongs to the Dongting Lake area. The elevation is approximately $30 \mathrm{~m}$ a.s.1. Three vegetated areas were chosen for study: 2 areas of poplar-one planted in 2000 (11-year poplar) and one planted in 2006 (5-year poplar) - and one of reed (planted in 2000 and harvested annually for paper making in November or December). Before establishment of the plantation using cuttings, the plant community in the study site comprised common herbaceous wetland plants, including Carex brevicuspis, T. sacchariflora, and Phragmites australis. The area covered by 11- and 5-year poplar was approximately 3 ha, and the area of reed was approximately 8 ha. The 3 vegetated areas were adjacent to one another, each separated by approximately $30-40 \mathrm{~m}$. Soils in all the study areas were of the same origin, and were deposited by flooding. Soil physical and chemical properties are similar among the 3 vegetated areas $(P>0.05)$. Mean soil $\mathrm{pH}$ at a depth of $0-60 \mathrm{~cm}$ is $8.01-8.22$. Total carbon, total nitrogen, total phosphorus, and total potassium are 21.59-25.25, 1.43-1.51, 0.70-0.73, and $19.35-22.51 \mathrm{~g} \mathrm{~kg}^{-1}$, respectively.

Measurement of vegetation parameters and soil water content

In each of the 3 vegetated areas, 3 fixed plots $(20 \mathrm{~m} \times 30 \mathrm{~m})$ with equal spacing were established as replicates. Stand density, height of vegetation, and diameter at breast height (DBH) of poplars were measured in October 2011. Multiple comparisons showed that the density of reed (148,000 plants $\left.\mathrm{ha}^{-1}\right)$ was significantly higher than that of 11-year poplar (833 trees $\mathrm{ha}^{-1}$, in rows spaced $3 \mathrm{~m} \times 4 \mathrm{~m}$ ) and 5 -year poplar (1,666 trees ha ${ }^{-1}$, in rows spaced $2 \mathrm{~m} \times 4 \mathrm{~m}$ ). The average height of vegetation in each of the 3 areas was 20.1, 10.5, and $3.7 \mathrm{~m}$ for 11-year poplar, 5-year poplar, and reed, respectively. The average DBH of 11- and 5-year poplar was 18.4 and $11.1 \mathrm{~cm}$, respectively. The average crown diameter of 11- and 5-year poplar was 3.95 and $3.08 \mathrm{~m}$, respectively.

Soil samples were collected from October 2011 to September 2012. In each plot, soil was sampled from 3 layers $(0-15,15-40$, and $40-70 \mathrm{~cm})$ using a soil sampler, according to the 5-point sampling method (Pobel et al. 2011). The latitude and longitude of each soil sampling point was recorded using a global positioning system. Soils within vegetated areas were mixed by soil layer, and stored in a bag for measurement of soil water content (SWC) using the classical method of drying and weighing (Dobriyal et al. 2012). Precipitation data from the meteorological station of the Dongting Lake Station for Wetland Ecosystem Research, located approximately $6 \mathrm{~km}$ from the study site, were used in this study.

Measurement of photosynthesis, stomatal conductance, and transpiration

On one cloudless day of each month during the 2012 growing season (May to September), a Li-6400 portable photosynthesis system (LI-COR, Inc., USA) was used to measure photosynthetic rate $\left(\mathrm{Pn}, \mu \mathrm{mol} \mathrm{m} \mathrm{m}^{-2} \mathrm{~s}^{-1}\right)$, stomatal conductance (Gs, mol m${ }^{-2} \mathrm{~s}^{-1}$ ), and transpiration rate $\left(\mathrm{Tr}, \mathrm{mmol} \mathrm{m} \mathrm{m}^{-2} \mathrm{~s}^{-1}\right)$. In poplar stands, 6 trees of average height and DBH were chosen as samples for 6 replicates. Ten fully expanded leaves from the north, south, east, and west parts of each sampled tree were selected and measurement were taken from approximately 50-60 leaves. In the reed area, 12 plants of average height were chosen as samples for 12 replicates. Four fully expanded leaves from the north, south, east, and west at the top of each sample were selected, and measurements were taken from a total of 48 leaves. All measurements were performed between 9:00 and 11:00 am. In May, June, and September, measurements were conducted during the middle 10 days of the month. However, measurements were conducted during the first 10 days of July and the last 10 days of August because parts of the plots were submerged by a flood from midJuly to mid-August. The water-use efficiency (WUE) of individual leaves was calculated as the ratio of $\mathrm{Pn}$ to $\mathrm{Tr}$ (Liang et al. 2006).

\section{Statistical analysis}

Multiple comparisons of density, height, DBH, and crown diameter in each of the 3 vegetated areas were 
analyzed by LSD at the 0.05 significance level, and monthly mean Pn, Gs, Tr, and WUE were analyzed by Tukey's test at the 0.05 significance level. Homogeneity of variances was tested using Levene's test, and data were $\log _{10}$-transformed when necessary to reduce the heterogeneity of variances. Correlation analyses among GS, Pn, and Tr were performed using bivariate correlations with two-tailed tests. Relationships among $\mathrm{Pn}, \mathrm{Gs}$, and $\mathrm{Tr}$ in the 3 vegetated areas were determined by curve regression (linear, power, logarithmic, or polynomial equations) on the basis of $\mathrm{R}^{2}$ and $P$ values. All statistical analyses were performed using SPSS v17.0 (SPSS Inc., USA).

\section{Results}

Precipitation and soil water content (SWC)

Monthly precipitation exceeded $100 \mathrm{~mm}$ from March to June, which was higher relative to that of other months (Fig. 1). During the investigation period, precipitation decreased from $60 \mathrm{~mm}$ in October to $7.1 \mathrm{~mm}$ in December, then increased to $205 \mathrm{~mm}$ in June and decreased to $51.0 \mathrm{~mm}$ in July, and finally increased to $92.4 \mathrm{~mm}$ in September.

SWC displayed similar seasonal dynamics to precipitation, and was relatively higher from March to September except in July (Fig. 2). For a given vegetated area, mean SWC during the study period was higher in the $0-15 \mathrm{~cm}$ soil layer than in the 15-40 and 40-70 cm layers. The reed area had higher SWC than the 11-year poplar in the $0-15 \mathrm{~cm}$ soil layer, and 11-year poplar had a higher SWC than the 5-year poplar except in December. In the $15-40 \mathrm{~cm}$ soil layer, SWC was higher in reed than in 11-year poplar except in August, and was higher in 11-year poplar than in 5-year poplar except in November and February. In the $40-70 \mathrm{~cm}$ soil layer, the SWC of reed was higher than that of 11-year poplar except in April and August, and the SWC of 11-year poplar was higher than that of 5-year poplar except in December and February. On the whole, SWC was highest in reed, intermediate in 11-year poplar, and lowest in 5-year poplar. For example, mean SWC in the $0-15 \mathrm{~cm}$ soil layer was 32.6, 28.6, and $25.3 \%$ in reed, 11- and 5 -year poplar, respectively. Therefore, it was clear that poplar plantations resulted in a lower SWC.

\section{Photosynthetic rate $(\mathrm{Pn})$}

The $\mathrm{Pn}$ of the 3 vegetated areas varied during the growing season, with different patterns (Fig. 3). In 11-year poplar, Pn decreased from $16.25 \mu \mathrm{mol} \mathrm{m}{ }^{-2} \mathrm{~s}^{-1}$ in May to $10.84 \mu \mathrm{mol} \mathrm{m} \mathrm{m}^{-2} \mathrm{~s}^{-1}$ in July, but increased to $17.58 \mu \mathrm{mol} \mathrm{m} \mathrm{m}^{-2} \mathrm{~s}^{-1}$ in September. In 5-year poplar, Pn decreased from $16.47 \mu \mathrm{mol} \mathrm{m}^{-2} \mathrm{~s}^{-1}$ in May to $9.98 \mu \mathrm{mol} \mathrm{m} \mathrm{m}^{-2} \mathrm{~s}^{-1}$ in July, but increased to $16.59 \mu \mathrm{mol} \mathrm{m}{ }^{-2} \mathrm{~s}^{-1}$ in August, and decreased to $13.55 \mu \mathrm{mol} \mathrm{m}{ }^{-2} \mathrm{~s}^{-1}$ in September. In reed, Pn increased from $23.24 \mu \mathrm{mol} \mathrm{m}{ }^{-2} \mathrm{~s}^{-1}$ in May to $28.34 \mu \mathrm{mol} \mathrm{m} \mathrm{m}^{-2} \mathrm{~s}^{-1}$ in July, but decreased to $16.05 \mu \mathrm{mol} \mathrm{m}{ }^{-2} \mathrm{~s}^{-1}$ in September.

From May through July, Pn was significantly higher in reed than in the two poplar stands, and did not differ between the different-aged poplars. In August, the Pn of 11-year poplar $\left(13.79 \mu \mathrm{mol} \mathrm{m} \mathrm{m}^{-2} \mathrm{~s}^{-1}\right)$ was lower

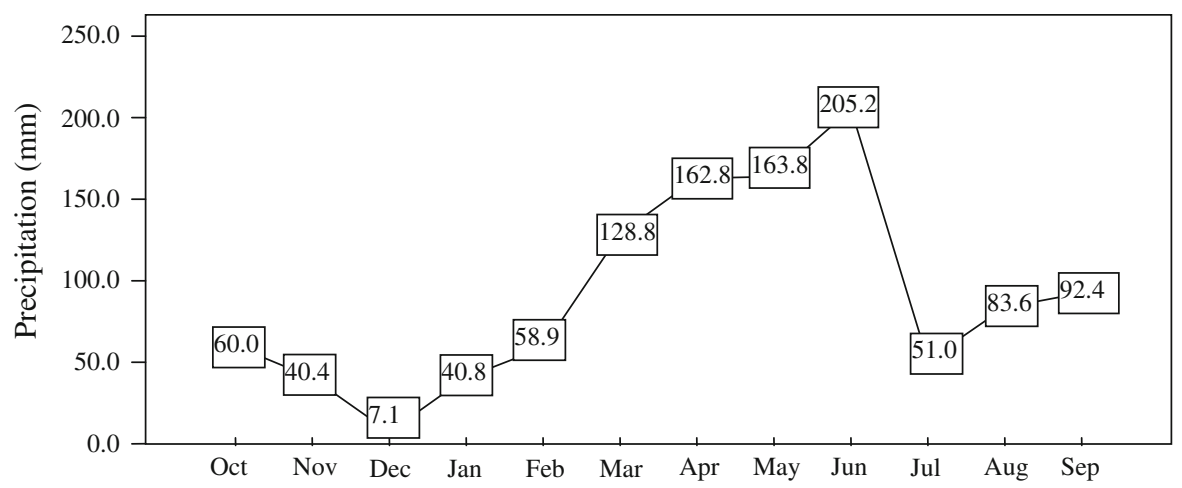

Fig. 1 Monthly precipitation during the study period (October 2011-September 2012) 


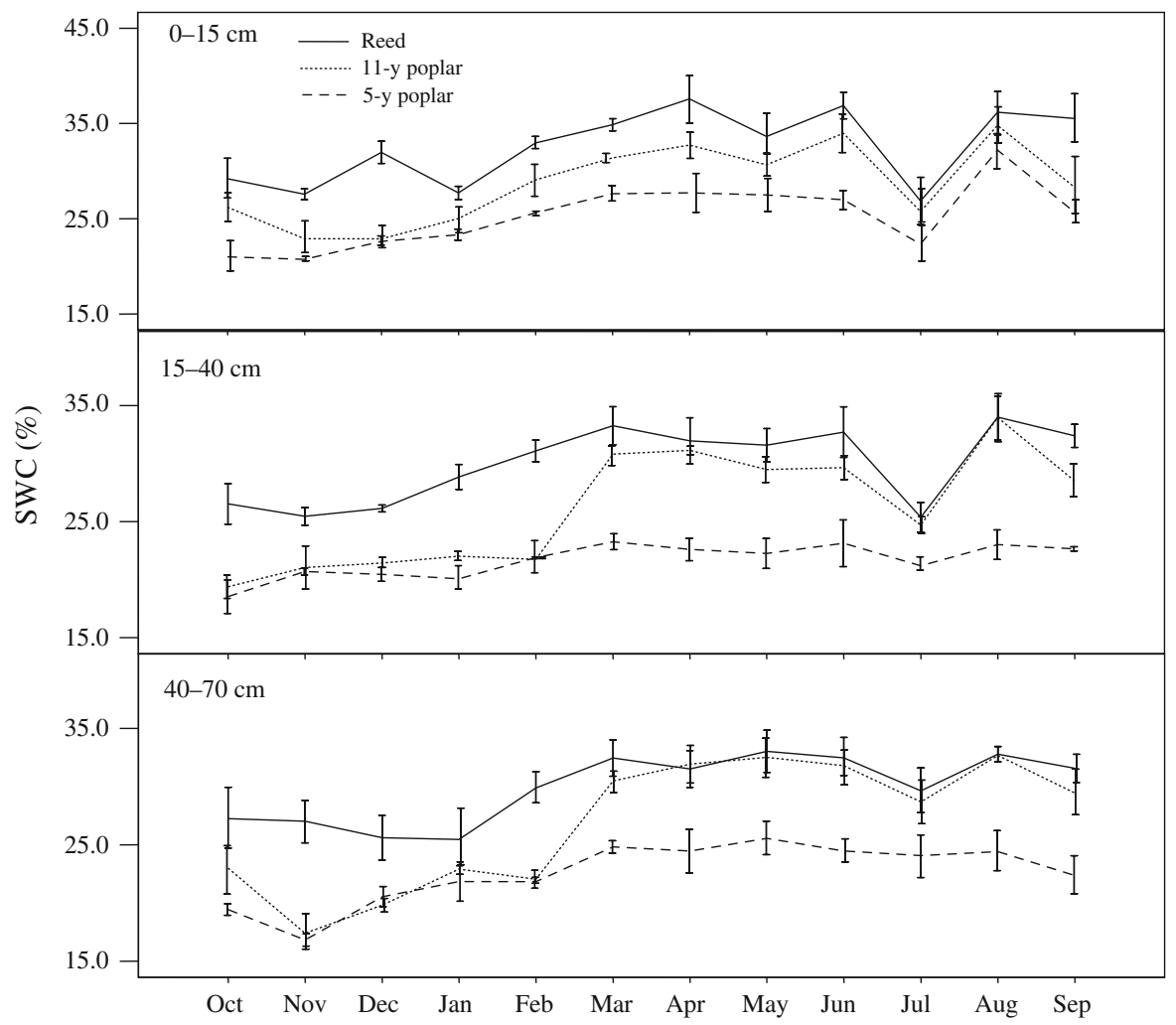

Fig. 2 Soil water content (SWC, mean $\pm \mathrm{SE}, n=3$ ) of the 3 vegetated areas examined during the study period (October 2011September 2012)
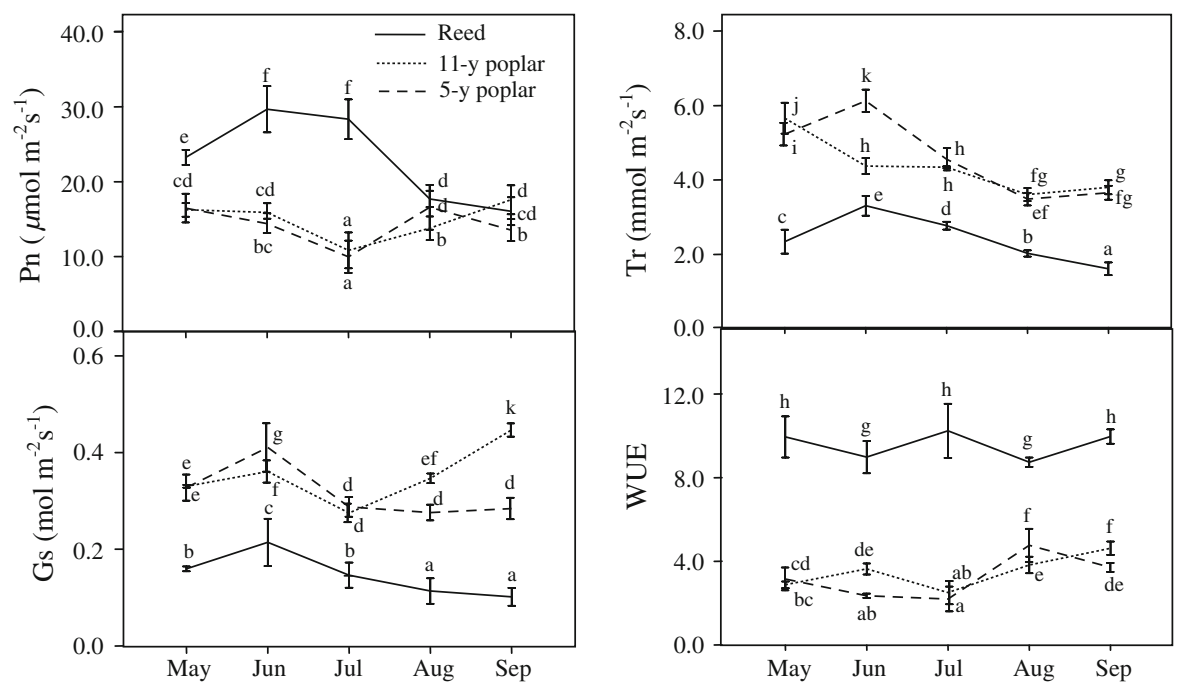

Fig. 3 Photosynthetic rate (Pn), stomatal conductance (Gs), transpiration rate (Tr), water-use efficiency (WUE) (mean \pm SE, $n=6$, 12) of the 3 types of vegetation during the 2012 growing season. Different letters indicate significant differences at $\alpha=0.05$

than that of 5-year poplar $\left(16.59 \mu \mathrm{mol} \mathrm{m} \mathrm{m}^{-2} \mathrm{~s}^{-1}\right)$ and reed $\left(17.69 \mu \mathrm{mol} \mathrm{m}{ }^{-2} \mathrm{~s}^{-1}\right)$. In September, the Pn of 5 -year poplar was lower than that of 11-year poplar or reed. On the whole, mean Pn in reed was approximately 1.6 times higher than that of 11 - and 5-year poplars, respectively. 
Stomatal conductance (Gs) and transpiration rate (Tr)

Over the growing season, the Gs of 5-year poplar and reed increased from May to June, but decreased in September (Fig. 3). However, the Gs of 11-year poplar increased from May to June, but decreased in July, and then increased in September. Gs was significantly higher in the poplars than in reed. Mean Gs in 11- and 5-year poplar was 2.39 and 2.16 times higher than that of reed, respectively. In June, Gs was higher in 5-year than in 11-year poplar, while in August and September, Gs was higher in 11-year than in 5-year poplar.

The $\mathrm{Tr}$ of 5-year poplar and reed increased from May to June, but decreased in September (Fig. 3). However, the Tr of 11-year poplar decreased from May to September. Tr was significantly higher in the poplars than in reed. Mean Tr in 11- and 5-year poplar was 1.81 and 1.91 times higher than that of reed, respectively. In May, Tr was higher in 11-year poplar than in 5-year poplar. In June, Tr was higher in 5-year poplar than in 11-year poplar. From July through September, Tr did not differ between the two poplar stands.

Water-use efficiency (WUE) of individual leaves

WUE differed significantly among months and vegetation types (Fig. 3). In 11-year poplar, WUE, in order from lowest to highest, was July $\leq$ May $<$ Jun $\leq$ August $<$ September. In 5-year poplar, WUE from lowest to highest was July $\leq$ June $<$ May $\leq$ September $<$ August. In reed, WUE was higher in May, July, and September than in June and August.

During the growing season, mean WUE in reed was 2.7 and 3.0 times higher than that of 11- and 5-year poplars $(P<0.001)$, respectively. In June and September, WUE was higher in 11-year (3.63 and 4.62) than in 5-year poplar (2.35 and 3.71). In August, WUE was higher in 5-year (4.76) than in 11-year poplar (3.82). In May and July, WUE did not differ between the two poplar stands.

\section{Relationships among Pn, Gs, and Tr}

Correlation analyses showed that Gs was positively correlated with $\mathrm{Pn}$ and $\mathrm{Tr}$ in the 3 vegetation types $(P<0.001)$. Pn was also positively correlated with $\mathrm{Tr}$ $(P<0.01)$. Relationships between $\mathrm{Pn}$ and Gs were linear in 11 -year poplar $(P<0.001)$ and were described by power functions in 5 -year poplar and reed $(P<0.001$, Fig. 4). Relationships between $\mathrm{Tr}$ and Gs were described by power functions in 11- and 5-year poplar $(P<0.001)$, and were linear in reed $(P<0.001)$. The relationships between $\operatorname{Tr}$ and $\mathrm{Pn}$ fitted a cubic function in 11-year poplar $(P<0.01)$, a quadratic function in 5-year poplar $(P<0.05)$, and a power function in reed $(P<0.001)$. Therefore, there was a stronger relationship among $\mathrm{Pn}, \mathrm{Tr}$, and $\mathrm{Gs}$ in reed than in the poplars.

\section{Discussion}

Soil water conditions reflect a balance between water influx and efflux. Rainfall is the most direct source of soil water, particularly for the ground surface (Grassini et al. 2010). In wetlands, soil water is also affected by flooding due to the high groundwater level (Xie et al. 2011). This may be the main explanation for similar seasonal changes in SWC and precipitation from January to August, and for the relatively higher SWC during the flood period (April to August). SWC was significantly lower in poplar stands than in reed, which is consistent with our first hypothesis. Previous studies have shown that poplar plantations can reduce the water table and desiccate soil in arid and semiarid areas (Chang et al. 2006; Wilske et al. 2009). Our study clearly showed that poplar plantations also reduced soil water content in wetlands.

Plant transpiration is the primary mechanism by which SWC is affected by the efflux of water from soil (Huang et al. 2011). Transpiration is positively correlated with Tr and leaf area index (Granier et al. 2000). In this study, Tr was higher in poplars than in reeds. Leaf area index is normally higher in trees than in herbaceous plants due to leaf stratification in trees (Wilske et al. 2009). Therefore, a higher Tr and a higher leaf area index might lead to the lower SWC in poplars compared to reed. Additionally, the $\operatorname{Tr}$ of poplars in Dongting Lake $\left(4.49 \mathrm{mmol} \mathrm{m} \mathrm{m}^{-2} \mathrm{~s}^{-1}\right)$ was higher than that in other regions, such as 2.93 in $40 \%$ field capacity reported in previous study (Liang et al. 2006). This higher Tr was largely due to the sufficient water supply for plant physiological requirements in wetlands. The higher Tr in poplar compared to reed is ascribed to the higher Gs in poplar due to the regulating role that leaf stomata play in water loss 

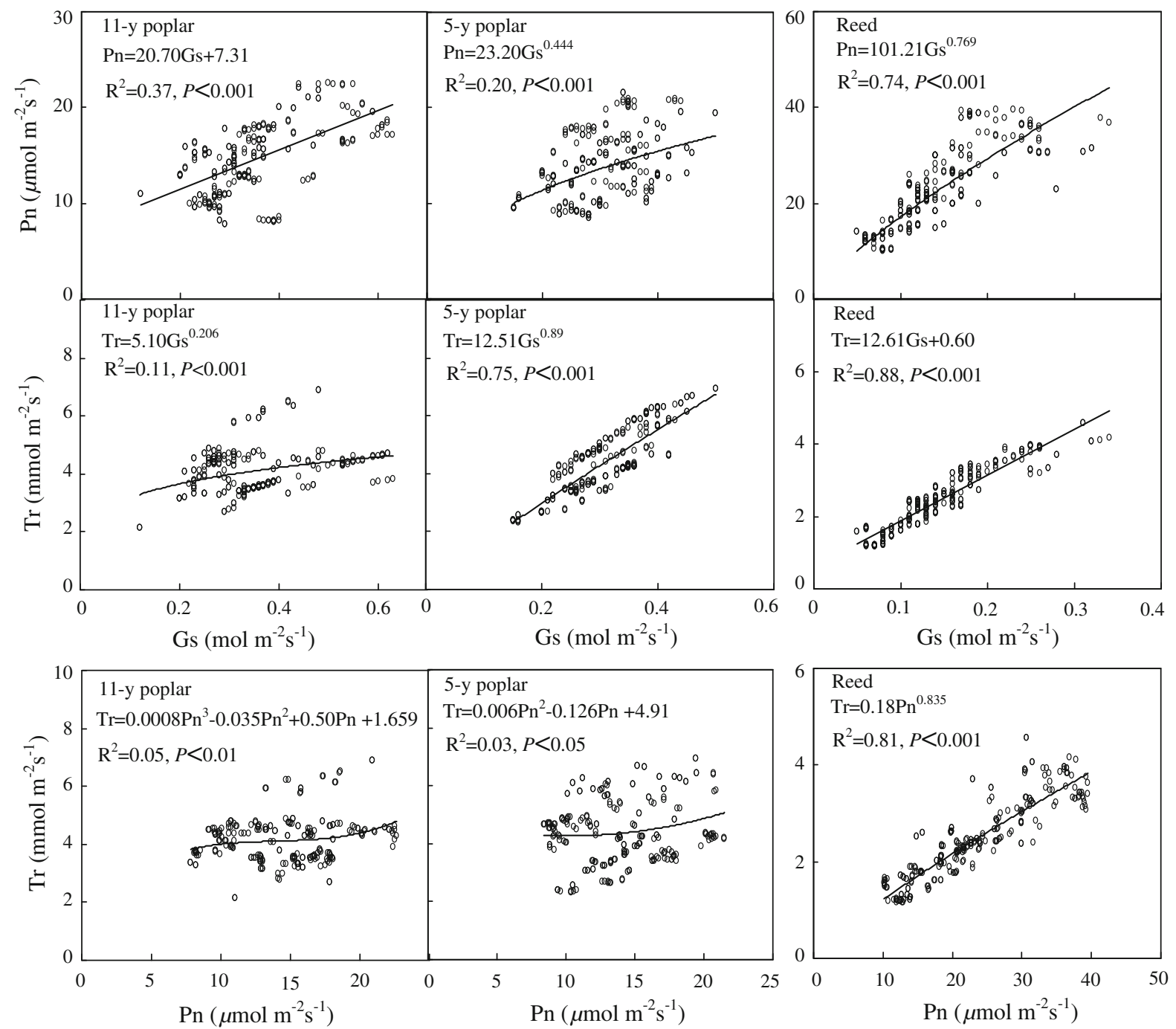

Fig. 4 Relationships among photosynthetic rate (Pn), stomatal conductance (Gs), and transpiration rate (Tr) in the 3 types of vegetation

(Huang et al. 2011), as supported by the positive relationship between Gs and Tr observed here and in previous studies (Chen et al. 2011). In this study, the $\mathrm{Tr}$ and Gs of the 3 vegetated areas did not exhibit seasonal changes similar to SWC, which is consistent with a majority of studies that have found little or no correlation between SWC and Tr (Fisher et al. 2008; Wallace and McJannet 2010). However, this finding differs from the dynamics observed in Acacia mangium stands and in a tropical mixed dipterocarp forest, where Gs was higher in wet than in dry conditions (Kumagai et al. 2004). This may be due to the high soil water availability in wetlands, or to the substantial rooting depths that are necessary to provide an adequate water supply during drier periods (Fisher et al. 2008). Therefore, the higher $\operatorname{Tr}$ and Gs in poplar compared to reed are the key physiological mechanisms underlying the reduction in soil water by poplar, consistent with our second hypothesis. However, the lower Pn observed in poplar compared to reed is contrary to the second hypothesis, but might be explained by the high productivity of reed (Heinsoo et al. 2011).

The higher SWC in 11-year poplars than in 5-year poplars suggests that transpiration may be lower in older poplar plantations. Two factors may contribute 
to this result. First, older stands might have a lower leaf area index (Almeida et al. 2007), which corresponds to lower stand transpiration (Delzon and Loustau 2005). Second, low stand density can result in low stand transpiration (Moreno and Cubera 2008). Therefore, both stand age and density may be important in regulating the reduction in soil water in poplar plantations.

The higher Pn in reed compared to poplar may indicate that reed has a better light-intercepting ability and a higher rate of dry matter accumulation than poplar. High productivity is dependent on high resource availability, such as that of water, solar radiation, and nutrients (Almeida et al. 2007; Fortier et al. 2010). The WUE of poplars in this study (3.36) was lower than that in other regions, such as 6.11 in $55 \%$ field capacity reported in other studies, indicating that the consumed water producing dry matter per unit increased from drought condition to water saturation condition (Liang et al. 2006). The lower WUE of poplar compared to reed suggests that poplar plantations require larger water supplies to satisfy their physiological requirements. Therefore, the high soil water loss and low WUE of poplar plantations could cause the transformation of wetlands into dry land, which, in turn, would influence community composition and ecosystem function (Engelbrecht et al. 2007; Gaitán et al. 2011). An example of such an effect was observed in the Southern Dongting Lake wetlands, where a poplar plantation led to a significantly lower diversity of migratory birds (Deng et al. 2008). As a wetland of international importance, some measures, such as the rational planning of poplar planting and wetland restoration, should be applied to protect the habitats of migratory birds in the Dongting Lake region.

In conclusion, our study clearly showed that poplar plantations had negative effects on soil water condition, even in the water-saturated wetlands, via high rates of transpiration and stomatal conductance. The greater soil water loss and lower water-use efficiency of poplars causes large amounts of water to be lost from wetlands, resulting in the desiccation of areas in which poplar plantations are established.

Acknowledgments This study was supported by the National Basic Research Program of China (2009CB421103, 2012CB417000), International Science \& Technology Cooperation Program of China (2012DFB30030), the National Nature Science Foundation of China (31170342) and Special
Funds for Scientific Research on Public Causes of Forestry Bureau of China (201104065).

Open Access This article is distributed under the terms of the Creative Commons Attribution License which permits any use, distribution, and reproduction in any medium, provided the original author(s) and the source are credited.

\section{References}

Almeida AC, Soares JV, Landsberg JJ, Rezende GD (2007) Growth and water balance of Eucalyptus grandis hybrid plantations in Brazil during a rotation for pulp production. For Ecol Manage 251:10-21

Chang X, Zhao W, Zhang Z, Su Y (2006) Sap flow and tree conductance of shelter-belt in arid region of China. Agric For Meteorol 138:132-141

Chen L, Zhang Z, Li Z, Tang J, Caldwell P, Zhang W (2011) Biophysical control of whole tree transpiration under an urban environment in northern China. J Hydrol 402:388-400

Chinese Forestry Society (CFS), National Poplar Commission (2003). Forest resource, timber production and poplar culture in China. In: 1st international conference on the future of poplar, Rome, Italy. http://www.fao.org/forestry/ site/20587/en/. Accessed 5 Jan 2013

Cui M, Zhou JX, Huang B (2012) Benefit evaluation of wetlands resource with different modes of protection and utilization in the Dongting Lake region. Procedia Environ Sci 13:2-17

Delzon S, Loustau D (2005) Age-related decline in stand water use: sap flow and transpiration in a pine forest chronosequence. Agric For Meteorol 129:105-119

Deng X, Dai M, Wang B, Yi H, Zhou B (2008) Monitoring of winter birds' community structure in the south Dongting Lake. Hunan For Sci Technol 35:36-39 (in Chinese)

Dobriyal P, Qureshi A, Badola R, Hussain SA (2012) A review of the methods available for estimating soil moisture and its implications for water resource management. J Hydrol 458-459:110-117

Engelbrecht BMJ, Comita LS, Condit R, Kursar TA, Tyree MT, Turner BL, Hubbell SP (2007) Drought sensitivity shapes species distribution patterns in tropical forests. Nature 447:80-82

Fang S, Xu X, Yu X, Li Z (2005) Poplar in wetland agroforestry: a case study of ecological benefits, site productivity, and economics. Wetlands Ecol Manage 13:93-104

Fisher RA, Williams M, de Lourdes RM, de Costa AL, Meir P (2008) Evaluating climatic and soil water controls on evapotranspiration at two Amazonian rainforest sites. Agric For Meteorol 148:850-861

Fortier J, Gagnon D, Truax B, Lambert F (2010) Nutrient accumulation and carbon sequestration in 6-year-old hybrid poplars in multiclonal agricultural riparian buffer strips. Agric Ecosyst Environ 137:276-287

Gaitán JJ, López CR, Bran DE (2011) Vegetation composition and its relationship with environment in mallines of north Patagonia, Argentina. Wetlands Ecol Manage 19:121-130 
Gerber JF (2011) Conflicts over industrial tree plantations in the South: Who, how and why? Global Environ Change 21:165-176

Granier A, Loustau D, Bréda N (2000) A generic model of forest canopy conductance dependent on climate, soil water availability and leaf area index. Annals For Sci 57:755-765

Grassini P, You J, Hubbard KG, Cassman KG (2010) Soil water recharge in a semi-arid temperate climate of the Central U.S. Great Plains. Agric Water Manage 97:1063-1069

Heinsoo K, Hein K, Melts I, Holm B, Ivask M (2011) Reed canary grass yield and fuel quality in Estonian farmers' fields. Biomass Bioenergy 35:617-625

Hernández-Santana V, David TS, Martínez-Fernández J (2008) Environmental and plant-based controls of water use in a Mediterranean oak stand. For Ecol Manage 255:37073715

Huang Y, Li X, Zhang Z, He C, Zhao P, You Y, Mo L (2011) Seasonal changes in Cyclobalanopsis glauca transpiration and canopy stomatal conductance and their dependence on subterranean water and climatic factors in rocky karst terrain. J Hydrol 402:135-143

International Energy Agency (IEA) (2004) Biofuels for Transport. An International Perspective, Paris

Kelty MJ (2006) The role of species mixtures in plantation forestry. For Ecol Manage 233:195-204

Kumagai T, Saitoh TM, Sato Y, Morooka T, Manfroi OJ, Kuraji K, Suzuki M (2004) Transpiration, canopy conductance and the decoupling coefficient of a lowland mixed dipterocarp forest in Sarawak, Borneo: dry spell effects. J Hydrol 287:237-251

Le Maitre DC, van Wilgen BW, Gelderblom CM, Bailey C, Chapman RA, Nel JA (2002) Invasive alien trees and water resources in South Africa: case studies of the costs and benefits of management. For Ecol Manage 160:143-159

Liang ZS, Yang JW, Shao HB, Han RL (2006) Investigation on water consumption characteristics and water use efficiency of poplar under soil water deficits on the Loess Plateau. Colloids Surf B 53:23-28

Licata JA, Gyenge JE, Fernández ME, Schlichter TM, Bond BJ (2008) Increased water use by ponderosa pine plantations in northwestern Patagonia, Argentina compared with native forest vegetation. For Ecol Manage 255:753-764

Migliavacca M, Meroni M, Manca G, Matteucci G, Montagnani L, Grassi G, Zenone T, Teobaldelli M, Goded I, Colombo R, Seufert G (2009) Seasonal and interannual patterns of carbon and water fluxes of a poplar plantation under peculiar eco-climatic conditions. Agric For Meteorol 149:1460-1476
Moreno G, Cubera E (2008) Impact of stand density on water status and leaf gas exchange in Quercus ilex. For Ecol Manage 254:74-84

Morris TL, Witkowski ETF, Coetzee JA (2008) Initial response of riparian plant community structure to clearing of invasive alien plants in Kruger National Park, South Africa. South African J Bot 74:485-494

Onyekwelu JC, Mosandl R, Stimm B (2006) Productivity, site evaluation and state of nutrition of Gmelina arborea plantations in Oluwa and Omo forest reserves, Nigeria. For Ecol Manage 229:214-227

Perry CH, Miller RC, Brooks KN (2001) Impacts of shortrotation hybrid poplar plantations on regional water yield. For Ecol Manage 143:143-151

Pobel D, Robin J, Humbert JF (2011) Influence of sampling strategies on the monitoring of cyanobacteria in shallow lakes: lessons from a case study in France. Water Res 45:1005-1014

Richards AE, Dalal RC, Schmidt S (2007) Soil carbon turnover and sequestration in native subtropical tree plantations. Soil Biol Biochem 39:2078-2090

Schiller G, Cohen S, Ungar ED, Moshe Y, Herr N (2007) Estimating water use of sclerophyllous species under EastMediterranean climate III. Tabor oak forest sap flow distribution and transpiration. For Ecol Manage 238:147-155

Tan ZH, Zhang YP, Song QH, Liu WJ, Deng XB, Tang JW, Deng Y, Zhou WJ, Yang LY, Yu GR, Sun XM, Liang NS (2011) Rubber plantations act as water pumps in tropical China. Geophys Res Lett 38:L24406

Wallace J, McJannet D (2010) Processes controlling transpiration in the rainforests of north Queensland, Australia. J Hydrol 384:107-117

Wilske B, Lu N, Wei L, Chen S, Zha T, Liu C, Xu W, Noormets A, Huang J, Wei Y, Chen J, Zhang Z, Ni J, Sun G, Guo K, McNulty S, John R, Han X, Lin G, Chen J (2009) Poplar plantation has the potential to alter the water balance in semiarid Inner Mongolia. J Environ Manage 90:2762-2770

Xie YH, Chen XS (2008) Effects of Three-Gorge Project on succession of wetland vegetation in Dongting Lake. Res Agric Modernization 29:684-687 (in Chinese)

Xie T, Liu X, Sun T (2011) The effects of groundwater table and flood irrigation strategies on soil water and salt dynamics and reed water use in the Yellow River Delta, China. Ecol Model 222:241-252

Yang G, Xie Y, Chen X, Li F, Ren B, Qin X (2009) Change of soil particle composition and chemical characteristics after "returning farmland to lake" in the Dongting Lake area. Acta Ecol Sin 29:6392-6400 (in Chinese) 